\title{
Em defesa das valências: uma réplica
}

In defense of sentiment analysis: a reply

Debates acerca de aspectos teóricos e metodológicos das ciências sociais não são muito comuns na academia brasileira. Claro, todo trabalho que se preza publicado nessas plagas contém algum "debate" teórico e, por vezes, metodológico, mas em geral esse "debate" se dá entre o autor brasileiro e autores-fonte internacionais, que raramente respondem a essas interpelações; diálogo sem volta. Não é o caso do presente artigo. Ele tem o propósito de responder a uma crítica feita por Luis Felipe Miguel acerca de aspectos teóricos e metodológicos relativos ao emprego da metodologia de análise de valências (MAV), particularmente nos estudos de mídia e política.

Em artigo na Revista Brasileira de Ciência Política, Miguel (2015) dedica-se a criticar veementemente a MAV, identificando entre seus praticantes Marcus Figueiredo, Alessandra Aldé, Felipe Borba, Pedro Mundim e, mais recentemente, as análises do site Manchetômetro (www.manchetometro.com).

Em texto anterior, escrito em conjunto com Flávia Biroli, Miguel já havia esboçado críticas a essa metodologia, mas de maneira breve (Biroli e Miguel 2013). Naquela oportunidade argumentaram que a MAV tinha dois problemas fundamentais: supor que seus resultados eram partilhados por jornalistas (emissores) e pelos mais variados segmentos do público (receptores), e que seria possível “mensurar a priori o impacto do noticiário 'positivo' ou

É professor do Instituto de Estudos Sociais e Políticos (lesp) da Universidade do Estado do Rio de Janeiro (Uerj) e coordenador do Grupo de Estudos Multidisciplinares da Ação Afirmativa (Gemaa) e do Laboratório de Estudos da Mídia e Esfera Pública (Lemep). E-mail: jferes@iesp.uerj.br. 
'negativo' sobre o público". De quebra, acrescentaram que esses problemas comprometeriam mais a aplicação da MAV do que a "dificuldade de mensurar seja o peso das diferentes matérias, seja seu grau de 'positividade' ou 'negatividade"' (Biroli e Miguel, 2013, p. 80).

Nesse novo artigo, de autoria exclusiva de Miguel, a MAV é tema central e objeto de crítica teórica e filosófica. Os argumentos são semelhantes, porém mais detalhadamente explorados e com tom mais radicalizado. Segundo ele, a MAV: (1) confunde emissor, receptor, pesquisador e objeto do discurso; (2) reduz drasticamente a complexidade do processo comunicativo; (3) reproduz o ideal normativo da imparcialidade jornalística; e (4) está sujeita à excessiva subjetividade.

Pretendo mostrar que esses argumentos arrolados por Miguel contra a MAV são, quando não equivocados, superficiais. Contra suas críticas argumento que estudos de valência: (1) enfocam o emissor somente, sem prejuízo para a análise; (2) reduzem complexidade como outras metodologias em ciências sociais; (3) não dependem do pressuposto da imparcialidade para serem feitos; e (4) estão menos sujeitos às distorções subjetivas do que metodologias de estudo da mídia como análise de agendamento e de enquadramento, defendidas pelo autor. Mostro também que Miguel cai em contradição ao criticar práticas que ele mesmo adotou durante sua prolífica carreira acadêmica na área dos estudos de mídia e política. Concluo argumentando que a MAV é análoga a outras técnicas de redução de complexidade do real e é plenamente integrável a outras metodologias empregadas nos estudos de mídia e política, como análise de enquadramento ou análise de agendamento, partilhando inclusive dos mesmos pressupostos teóricos.

\section{As críticas à MAV}

No texto, Miguel (2015) levanta quatro objeções principais contra a MAV. São elas:

1. "Ela confunde sistematicamente diferentes planos de apreensão do jornalismo, colocando na mesma panela emissor, receptor, pesquisador e objeto do discurso. Em particular, ela introduz de contrabando uma presunção de compreensão da recepção das mensagens jornalísticas, poupando-se o trabalho de fazer pesquisa de recepção" (p. 165-166). 
2. "Ela necessariamente mutila a complexidade do processo comunicativo, a fim de adequá-lo a sua escala de "bom" e "mau", no caminho mutilando também a complexidade da interface entre mídia e competição política. O que se perde com isso não é acessório, é o principal" (p. 166).

3. "A valência reproduz, mesmo que muitas vezes de forma oculta, o ideal normativo da imparcialidade jornalística. O que a valência mede é o desvio em relação a essa imparcialidade" (p. 166).

4. Com a MAV "cresce a possibilidade de erro humano - ou, melhor dizendo, de divergência na classificação, que sempre inclui um componente subjetivo" (p. 172).

$\mathrm{O}$ autor conclui que por essas razões a MAV não deve ser adotada e em seu lugar sugere o emprego das análises de agendamento e de enquadramento no estudo da mídia. Nas seções que seguem, abordo cada uma dessas críticas em detalhe e aponto suas fragilidades e contradições, usando trabalhos do próprio Miguel e de outros autores das ciências sociais como exemplos ilustrativos de meus argumentos.

\section{Planos de apreensão do jornalismo}

A crítica de que a MAV faz vistas grossas aos diferentes planos de apreensão do jornalismo está diretamente ligada à concepção perspectivista que Miguel tem da sociedade, particularmente no que toca os pontos de vista morais e o uso da linguagem (Miguel e Biroli, 2010; Miguel 2011). Para ele, a vida social não produz acordos normativamente consensuais, mas apenas diferentes perspectivas sobre os fatos, interesses e valores, marcadas pelas diferentes posições sociais e culturais dos agentes. Desse diagnóstico ontológico sobre o mundo social, deriva a conclusão de que os codificadores não seriam capazes de atribuir valências (positivas, negativas ou neutras) que sejam válidas para a audiência em geral.

Voltaremos à questão dos parâmetros de subjetividade da MAV na última seção, quando compararmos essa abordagem a outras preferidas por Miguel. Por enquanto basta notar que o autor não fornece qualquer evidência empírica de sua afirmação de fato acerca da dissonância que incidiria sobre o processo de codificação. Ao contrário do que ele supõe, contudo, os trabalhos que utilizam a MAV são baseados na ideia de que podemos desacoplar emissão de recepção e, assim, estudar somente a emissão. Isso 
porque a linguagem tem significados consensuais partilhados pela imensa maioria dos falantes da língua. Ou seja, os entendimentos são intersubjetivos e somente por meio deles é que, por exemplo, Miguel consegue escrever um texto com a expectativa de que seus leitores o compreendam. Claro, digo isso assumindo que o autor partilha dessa pretensão comigo e com grande parte da comunidade acadêmica. Se não fosse assim, o mundo dos humanos seria impossível, inviável, uma babel.

A influência de pensadores como Michel Foucault e Jacques Derrida nas ciências sociais e humanidades tem produzido uma onda de ceticismo epistemológico que muitas vezes beira o niilismo. Do primeiro advém uma postura radicalmente construtivista, na qual toda pretensão de verdade é entendida como produto de mecanismos de poder e controle (universidade, exército, mídia etc.) (Foucault, 1979). Derrida, por seu turno, com o conceito de différance introduziu a ideia de que o significado das palavras de fato nunca se fecha, já que qualquer definição utiliza outras palavras cujas definições conduzem ainda a outras palavras, num processo de infinita recorrência (Derrida, 1978). O impacto do pensamento desses dois autores, particularmente de seus elementos mais céticos, foi grande na academia norte-americana, e daí para o resto do mundo. Um dos produtos desse processo foi a adoção de um perspectivismo radical que entende a sociedade como dividida em posições de raça, gênero e cultura irredutíveis e, em última instância, irreconciliáveis por meio da representação política agregativa ou mesmo da comunicação linguística.

É impressionante notar que esse perspectivismo radical, adotado frequentemente com fervor na academia e nos movimentos sociais para criticar estruturas de poder e opressão, pode também servir para o projeto de tentar calar a crítica, como é o caso de Miguel nesse texto. Com raríssimas exceções, a grande mídia brasileira tem tido um papel histórico extremamente deletério para o avanço das instituições da democracia, da igualdade e da pauta de direitos da cidadania. Combateram o presidente eleito Getúlio Vargas de maneira determinada, tentaram impedir a posse de seu sucessor, Juscelino Kubitschek, e apoiaram dois golpes militares contra João Goulart - o segundo, em 1964, suspendeu o regime democrático e o estado de direito em nosso país por vinte anos. Apoiaram veementemente essa ditadura militar, e a partir do processo de democratização passaram a militar contra candidatos de esquerda em eleições, particularmente contra o Partido dos 
Trabalhadores (PT), como mostra extensíssima literatura acadêmica da qual Miguel é um dos autores (Miguel, 1999b, 2002b, 2004b).

Os estudos de valência são capazes de capturar esse viés de modo preciso, no seu valor bruto, para além das sutilizas que caracterizam cada texto. Miguel acusa estudos como o do Manchetômetro de dar verniz acadêmico [sic] "às denúncias de viés da mídia contra a candidata presidencial à reeleição, Dilma Rousseff" (Miguel, 2015, p. 166). Já seus trabalhos acusando viés da grande mídia contra o PT nas eleições presidenciais de 1989, 1994, 1998 e 2006 não seriam tentativas de dar verniz acadêmico a sua posição política? Essa pergunta aceita duas respostas somente: sim, e então estaríamos como bons céticos reduzindo todos esses esforços de produção de conhecimento científico à vala comum da vontade de poder. A resposta positiva não parece ter sido a almejada por Miguel, pois, se fosse, ele deveria ter declarado que seus trabalhos também eram obra de carpintaria, no pior sentido da metáfora que ele mesmo emprega. Assim, a resposta mais provável é a negativa, ou seja, essa acusação feita por Miguel é baseada no juízo de que as metodologias que empregou são mais sólidas e científicas que a MAV. Responderemos essa questão quando compararmos a MAV a outras metodologias utilizadas nos estudos de mídia. Claro, está fora de propósito aqui considerar tal afirmação feita por Miguel como uma imprecação ad hominen de caráter leviano, carente de rigor e de autocrítica. Não precisamos deslindar esses meandros psicológicos para provarmos que o autor esposa uma posição equivocada.

Ainda no que toca a crítica dos diferentes planos da comunicação, supostamente perdidos pela MAV, Miguel diz que a negatividade ou positividade da cobertura de um tema ou candidato não pode ser determinada sem levarmos em conta o contexto da recepção. E acrescenta que "ser alvo do ataque significa ser reconhecido como polo da disputa, o que pode ser um aspecto importante da estratégia política", logo em seguida dando o exemplo hipotético dos benefícios que Luciana Genro teria por ter sido atacada por Aécio Neves (Miguel, 2015, p. 175). O exemplo é surpreendente, pois a discussão é sobre cobertura de mídia e não sobre ataques entre candidatos. Mas sejamos pacientes e suponhamos que o exemplo fosse sobre uma hipotética cobertura negativa de Luciana Genro por parte da grande mídia. Ora, por ser um estudo de emissão, a MAV não tem poder de determinar quais as consequências da cobertura mais ou menos negativa para um dado candidato. O bom senso indica que, de fato, para um candidato muito pouco conhecido 
o aumento de sua exposição pública pela mídia, mesmo que negativa, lhe traz algum benefício eleitoral.

O estudo feito pelo Manchetômetro, empregando a MAV, da cobertura da campanha de Marina Silva em 2014, denominado Marinômetro (www. manchetometro.com.br/marinometro), fornece pistas de que a superexposição que a candidata recebeu por parte da grande mídia foi um dos elementos responsáveis por catapultar seu crescimento nas pesquisas de intenção de voto. Contudo, ele também sugere que o excesso de cobertura negativa da candidata contribuiu para sua posterior queda nas intenções. Mas essas são somente evidências que necessitam de investigações de outra natureza para serem confirmadas.

A despeito do problema já identificado, o exemplo escolhido por Miguel peca por outra razão: enfocar o problema do candidato desconhecido. É claro que para um candidato desconhecido qualquer exposição é lucro. Mas nas eleições presidenciais brasileiras temos há décadas um embate entre candidatos muito conhecidos de dois partidos muito conhecidos. Para esses candidatos, o efeito positivo do desconhecimento não funciona. Assim, é razoável supor que para eles a cobertura negativa é, sim, deletéria às suas pretensões eleitorais, e que quanto mais negativa, pior.

Voltando à questão da perspectiva interpretativa de diferentes posições sociais, longe de mim negar que a recepção de um texto jornalístico não possa ser complexa e variar de pessoa a pessoa. Da mesma forma, a expressão jornalística também pode ser mais ou menos complexa. Mas é aí que entra a capacidade do pesquisador de adequar a metodologia ao objeto. Entramos assim no campo da segunda objeção.

\section{Redução da complexidade do objeto}

Em seu artigo, Miguel (2015) fala de complexidades, áreas gris, ambiguidades etc., mas se esquece de notar que esses são elementos de análise adequados ao trabalho qualitativo. Ele parece achar impróprias análises que tomem toda a cobertura de grandes mídias, a despeito de elas serem de fato feitas no Brasil (Aldé, 2003; Aldé, Mendes e Figueiredo, 2007) e no exterior (Hopkins e King, 2010; King, Pan, e Roberts, 2013). Certamente não é possível fazer uma análise qualitativa de toda a cobertura jornalística eleitoral, por falta de recursos e métodos adequados. Assim, a abordagem qualitativa só funciona quando aplicada a um ou dois textos, uma dezena 
no máximo. Mas se isso é verdade, ou seja, se estudos quantitativos de larga escala são inapropriados, e se só resta análises qualitativas com limitado número de casos, como parece querer Miguel, então o estudo abrangente do comportamento da grande mídia, fundamental para a discussão acerca do funcionamento da democracia em nosso país, estaria interditado.

Talvez o autor esteja defendendo interpretações abrangentes da grande mídia feitas de maneira impressionística, sem qualquer critério para verificação de generalizações feitas a partir da análise qualitativa de poucos casos. Mas se critérios de generalização não são fornecidos, então a credibilidade de tais generalizações repousa exclusivamente na autoridade de quem as faz, isto é, o autor. Em trabalho recente sobre a história da ciência política no Brasil, Fernando Leite chama essa abordagem de humanística, e associa a figura do intelectual público diletante no contexto anterior à institucionalização da pesquisa e da pós-graduação em nosso país (Leite, 2015). A despeito do rápido avanço da institucionalização da ciência política no Brasil (Lamounier, 1983; Marenco, 2015), ainda hoje há quem cometa tal modalidade de análise. De fato, há bastante lugar para tal abordagem no debate público, inclusive pela mão de acadêmicos profissionais, mas se trata de prática inaceitável nas ciências sociais. Substituir o método pela suposta autoridade ou verve literária do autor é voltar aos tempos em que o beletrismo e o bacharelismo imperavam. Qualquer método, por mais falho que seja, já é avanço em relação a isso, pois pelo menos se abre à crítica e ao aprimoramento. Como pretendemos mostrar adiante, a MAV não só é capaz de produzir análises de extensos corpora de textos prenhes de significado, como tem sido capaz de produzir resultados consoantes com o resto da literatura de mídia e política em nosso país, o que confirma seu valor operacional. Em suma, o monismo metodológico, implicitamente assumido por Miguel, a favor do trabalho qualitativo em detrimento "dos números" é perigosamente paralisante, se não arcaizante. Não há razão para que, em um contexto de maturidade e pluralidade do campo, métodos qualitativos e quantitativos não possam existir e, inclusive, serem combinados em análises mais complexas.

Ao contrário do que Miguel afirma, o estudo de valências não é epistemologicamente ingênuo, muito pelo contrário. Aristóteles dizia que a precisão de nosso conhecimento varia de acordo com a natureza de seu objeto (Aristóteles, 2000, I.3). Traduzindo para nossa problemática, a MAV não é um apanágio universal dos estudos de mídia. Ela se adequa a alguns objetos 
e contextos e não a outros. Por exemplo, o estudo da recepção midiática do affair Caçadas de Pedrinho, ${ }^{1}$ o qual coordenei, não estuda valências, mas enquadramentos (Feres Júnior, Nascimento, e Eisenberg, 2013). Em artigo recente, acerca do uso do argumento do creamy layer no debate sobre as políticas de ação afirmativa na grande mídia, utilizamos análise qualitativa combinada com alguns números aqui e acolá, pois é sempre bom tentar mostrar que o nosso objeto de análise não é extraordinário, evitando assim a possibilidade de que ele seja um outlier, em linguagem estatística (Feres Júnior e Daflon, 2015). E no imenso projeto sobre o tratamento que a grande mídia deu às políticas de ação afirmativa, usamos MAV e análise de enquadramentos (Campos, Daflon e Feres Júnior, 2013). Em suma, não há solução simples ou única, mas diferentes objetos de pesquisa e metodologias que são aplicadas ao seu estudo com o intuito de produzir análises que tenham significado para audiências acadêmicas e, quiçá, de fora da acadêmica.

A crítica mais frágil feita por Miguel (2015, p. 116), contudo, é a de que a MAV “mutila a complexidade do processo comunicativo". Ela é insustentável. Ora, a ciência opera exatamente por meio da redução da complexidade do mundo. Caso contrário, nós, humanos, estaríamos ainda perplexos perante o mundo natural, vivendo em cavernas, com nossas costas voltadas para a entrada. $\mathrm{O}$ ponto não é se tal ou qual metodologia opera uma redução do real, pois todas que funcionam fazem isso, mas se podemos reduzi-lo a uma escala "bidimensional", palavra utilizada por Miguel para atacar a MAV².

A resposta é afirmativa: sim, podemos, quando os textos com os quais trabalhamos adotam posições polares, dicotômicas, sobre seu objeto, isto é, são claramente contrários ou favoráveis. Acontece que é exatamente essa a natureza da cobertura eleitoral. Sabemos de antemão, da literatura sobre estudos de mídia e política no Brasil, da qual Luis Miguel e Flávia Biroli são expoentes (Miguel, 2004a, 1999b, 2003; Biroli e Miguel, 2013), que a grande mídia brasileira tem sistematicamente mostrado viés antiesquerda, antipetista. Os trabalhos que apontam para esse resultado - usando todo

1 No segundo semestre de 2010, a Câmara de Educação Básica do Conselho Nacional de Educação (CEB/ CNE) elaborou dois pareceres em resposta a solicitação feita pela Ouvidoria da Secretaria de Políticas de Promoção da Igualdade Racial (Seppir) acerca de denúncia contra a veiculação de "preconceitos e estereótipos contra grupos étnico-raciais" contidos no livro Caçadas de Pedrinho, de Monteiro Lobato. O caso ganhou grande visibilidade e gerou uma intensa controvérsia midiática.

2 O termo mais correto, na verdade, seria linear, pois trabalhos como os de Aldé e Figueiredo ou o do Manchetômetro utilizam pelo menos três valores de valência (favorável, contrária e neutra). 
tipo de metodologia, da quali mais simplória à quanti mais sofisticada, ou vice-versa - são legião (Kucinski, 1998; Souza, 2009; Figueiredo, 1996; Gonçalves, 1996; Arruda, 1995; Miguel, 1999b; Colling, 2000; Azevedo, 2000; Miguel, 2002a).

Sabemos também, por meio dos mesmos trabalhos acadêmicos, que os grandes veículos de mídia brasileiros se concentram em um espaço limitado do espectro ideológico. E, por fim, a análise mais superficial da cobertura diária de capas de jornais e de seu miolo, bem como do Jornal Nacional, do Jornal da Globo etc., revela que notícias são claramente editadas com o intuito de prejudicar a imagem de candidatos, políticos e partidos, quase sempre do PT e aliados. A cobertura da política, particularmente no período eleitoral, é extremamente pobre de sutilezas, pluralismo de opiniões, perspectivas, "processos contraditórios e multifacetados", como quer nosso autor. Não é a MAV que imprime dicotomização excessiva, o corpus da cobertura jornalística já se apresenta dicotomizado na fonte.

Por essa mesma razão é que adotamos a MAV em nosso estudo do tratamento dado pela mídia às políticas de ação afirmativa, feito em colaboração com Luiz Augusto Campos e Veronica Toste, entre outros (Campos, Feres Júnior e Daflon, 2013a; Daflon e Feres Júnior, 2012), pois a grande mídia representou o debate de maneira altamente polarizada.

Mas reduções da complexidade muito similares à feita pela MAV são comuns na prática científica. Tomemos como exemplo de comparação a identidade de cor/raça. No mundo real, ela se constitui por meio de processos multifacetados de negociação entre indivíduo e sociedade, que levam em conta aspectos históricos, biográficos, de classe social, linguísticos, psicológicos, físicos etc. Mesmo se tomarmos somente o aspecto da autoidentificação étnico-racial, ela se expressa por meio de dezenas ou mesmo centenas de termos no Brasil (Schwartzman, 1999), a despeito da baixa significância estatística da maioria deles. Não obstante tal complexidade, cientistas sociais frequentemente reduzem tal identidade a dois ou três valores (brancos e não brancos; brancos, pretos e pardos) ou, para citar os termos que Miguel usa com claro intuito derrogatório, a uma "escala linear, gráficos, pizza" (Hasenbalg, 1992; Hasenbalg e Silva, 1988; Silva, 1978, 1981). Ora, sem esses trabalhos de análise quantitativa das desigualdades raciais ficaríamos, no Brasil, presos ao achismo das análises qualitativas e incapazes de chegar a consensos públicos que possam legitimar políticas de mitigação desse estado 
de coisas. Nunca é demais lembrar que o argumento usado pelos adversários de tais políticas era análogo ao de Miguel: a raça no Brasil é um fenômeno muito complexo para ser reduzido a padrões estáveis de comparação (Fry e Maggie, 2003; Maggie e Fry, 2004).

$\mathrm{Na}$ verdade, o valor heurístico dessa comparação com o estudo das relações raciais vai além. Tomemos o exemplo de trabalho recente de Luiz Augusto Campos e Carlos Machado (2015), cujo objeto de estudo é a representação de não brancos (pretos e pardos) nas funções de candidatos e eleitos para câmaras legislativas. Os autores optam pela metodologia da heteroclassificação para determinar a identidade racial de candidatos e eleitos, dada a dificuldade de se obter esse dado por outros meios. Ou seja, um grupo pequeno de pesquisadores arbitra a identidade avaliando uma fotografia do candidato. Esse procedimento comete as duas violações que Miguel reputa à MAV. Ela achata os planos de compreensão da identidade racial. Na vida real, tal identidade pode, às vezes, ser usada de maneira instrumental e também variar entre "portador" e "receptor". Na pesquisa, ela é fixada pelo olhar dos pesquisadores, à revelia do que cada sujeito pensa e de como se identifica (análogo à intenção do jornalista) ou a como ele é percebido por outros (análogo à recepção do texto jornalístico). Ao fazer isso a abordagem de Campos e Matos também reduz a complexidade de seu objeto. Como já argumentamos, isso é uma obviedade; resta saber se tal redução é cientificamente justificável - o que ela de fato é. A falta de dados acerca da identidade racial justifica tal escolha, mas, acima de tudo, como vários estudos anteriores já mostraram, as categorias raciais do Instituto Brasileiro de Geografia e Estatística (IBGE) utilizadas pelos autores funcionam bem para explicar as desigualdades raciais no Brasil. Nada mais razoável do que as aplicá-las à análise de mais essa desigualdade, tão pouco estudada: a representação política.

É irônico constatar que o próprio Miguel afirma, ao comentar a cobertura do Jornal Nacional e da grande mídia, que ela privilegia a dramatização narrativa da notícia, como nas telenovelas: "mostrando a luta do 'bem' contra o 'mal'” (Miguel, 2002a, p. 72). Ora, é exatamente esse maniqueísmo que possibilita o emprego da MAV. Se os textos são de fatos dicotomizados, por que devemos nos furtar a fazer essa redução metodológica, se ela nos possibilita avaliar grandes quantidades de texto? A despeito da enorme contradição, é isso que o professor da UnB preconiza em seu trabalho. 
As ironias não param por aí. Em texto escrito em conjunto com Carlos Machado, Miguel propõe duas medidas para classificar coligações partidárias: índice de viés ideológico (IVI) e índice de governismo federal (IGF) (Machado e Miguel, 2011). Cada um desses índices funciona como uma "escala linear" na qual todos os partidos são classificados. A distribuição dos partidos segundo esses índices é então representada em um "gráfico" bidimensional. Depois vemos mais tabelas com mais escalas lineares que classificam partidos de acordo com sua coerência, coesão e consistência. Em suma, um objeto tão complexo como uma coligação partidária, que encerra várias perspectivas (eleitores, políticos, burocratas de partido, financiadores de campanha, interesses corporativos, interesses de movimentos sociais etc.), é reduzido a escalas lineares quantitativas e representado em gráficos, prática que ele acusa a MAV de perpetrar.

A única explicação possível para tal incoerência por parte do autor é a de que o objeto da MAV, a comunicação política, seja de um grau de complexidade muito superior a de outros fenômenos quantificáveis, como identidades raciais e coligações eleitorais. Mas esse argumento nunca é enfrentado no texto de Miguel, que se limita a dizer que há objetos quantificáveis, mas que a valência não é. $\mathrm{Na}$ falta de argumento sólido, só resta ao leitor ter fé na autoridade da opinião do autor.

\section{O pressuposto da imparcialidade}

A crítica mais comum feita à MAV, particularmente vinda dos autores da comunicação, é a de que o ideal de imparcialidade jornalística constitui a base normativa sine qua non sobre a qual se assenta a metodologia. Miguel partilha dessa posição. Contudo, a fragilidade filosófica dessa crítica é gritante. Miguel parece confundir o ideal normativo da imparcialidade com a questão da possibilidade prática da imparcialidade, ou seja, o "dever ser" com o "poder ser". Os estudos que utilizam a MAV não precisam aderir ao ideal normativo, nem tampouco à possibilidade prática, pois a questão da imparcialidade é externa à MAV. A posição de Miguel é análoga a dizer, emprestando um exemplo da sociologia, que a medida da desigualdade de renda entre as pessoas depende da adesão ao ideal normativo da igualdade material ou mesmo à possibilidade prática de igualdade entre as pessoas ${ }^{3}$.

3 É bom ter claro que as pessoas podem aderir a um ideal normativo tendo plena consciência de sua impossibilidade prática, ou seja, que o mundo real nunca atingirá tal ideal. Teorias ideiais, como o liberalismo igualitário de John Rawls, funcionam assim. 
Permitindo-me uma anedota biográfica ainda do mundo da sociologia. A orientação ideológica dos pesquisadores que estudam desigualdades que conheço varia do igualitarismo fervoroso até posições quase libertárias, que tomam as desigualdades socioeconômicas como resultado inescapável da competição "salutar" de mercado. Não obstante, todos usam os mesmos parâmetros e métodos de medida no estudo de seu objeto.

Em outros termos, não precisamos supor qualquer critério de imparcialidade para fazer análise de valência. A valência diz respeito ao texto e a seu objeto e determina se o texto é favorável ou não ao objeto. Tudo o mais dito por Miguel são suposições teóricas infundadas. Vejamos o exemplo que ele dá no texto: "Um tratamento equânime - viés negativo para todos os candidatos a uma eleição, por exemplo - seria indicativo da imparcialidade" (Miguel, 2015, p. 167). Ao importar o termo imparcialidade, Miguel tenta fazer com a análise de valência aquilo que ele a acusa de fazer com os estudos de mídia. Mas não devemos nos deixar enganar por esse artifício retórico. Os estudos de valência avaliam, contam e comparam valores (positivo, negativo e neutro). Fica a cargo do leitor concluir, por exemplo, ao se deparar com o mesmo viés "negativo para cada candidato", que aquilo constitui imparcialidade. Ele pode achar, por exemplo, que um candidato merece cobertura bem mais negativa, e que a mídia está “aliviando para seu lado". Ou que outro candidato está sendo tratado de maneira desfavorável por receber mais cobertura negativa do que merece, ao ser igualado aos outros. Ou ainda entender tal tratamento negativo igual como uma disposição geral da mídia contra a política e o processo eleitoral.

Melhor ainda, vamos tomar as concepções normativas conforme sistematizadas pelo próprio Miguel para mostrar como sua crítica à MAV é destituída de fundamento. Em artigo que discute os modelos de comunicação de massa preconizados por diferentes teorias democráticas (Miguel, 2004c), o autor associa os seguintes ideais normativos ao conteúdo do que é vinculado: a teoria liberal-pluralista almeja que o conteúdo da comunicação reflita a "pluralidade gerada pelo mercado"; a teoria deliberativa (esfera pública), a discussão imparcial; e a democracia radical, a "pluralidade promovida por mecanismos extramercantis". Segundo o autor, as vertentes liberal e deliberativa primam pelo ideal normativo da imparcialidade, enquanto a democrática radical reconhece que "a informação sempre reflete os interesses dos emissores” (Miguel, 2004c, p. 135). Não vou me ater aqui a algumas 
imprecisões conceituais, como a de imputar imparcialidade à teoria liberal ou mesmo a de assumir que a "imparcialidade" preconizada pela teoria deliberativa constitui neutralidade e não a ausência de distorções causadas pela interferência de interesses de mercado e do poder administrativo, algo bem diferente de neutralidade. Basta notar o seguinte: perante o resultado hipotético de uma pesquisa de análise de valências que mostre viés decidido contra um candidato ou partido, o liberal pode concluir que esse viés é justo (moralmente correto), pois se a mídia está aberta ao mercado, qualquer resultado que ela produza é justo. O próprio Miguel conclui que para os liberais a mídia é um "não problema" (Miguel, 2004c, p. 135). O deliberacionista, por seu turno, pode de fato tomar o viés excessivo como um sinal de que deve haver captura dos meios de comunicação por interesses de mercado ou de governo. Mas isso não é necessariamente verdadeiro. $O$ viés contrário a um candidato pode ser produto de fatos e opiniões arrolados contra ele em um processo deliberativo justo, no qual os argumentos são formulados segundo as normas da reciprocidade e da razão pública. Por fim, o democrata radical pode concluir que o viés é produto do somatório de posições contrárias a um candidato por meios que expressam uma pluralidade de pontos de vista não submetidos ao filtro do mercado. Em suma, o viés tem significado sob qualquer dessas perspectivas normativas e independe de qualquer uma delas para ser determinado.

\section{Subjetividade, MAV, agendamento e análise de enquadramento}

Miguel não demora, contudo, a adotar a crítica mais senso comum contra a MAV:

A atribuição do caráter positivo, negativo ou neutro carrega uma indiscutível carga de subjetividade. A indicação de como determiná-la para cada matéria inclui, de maneira central, a compreensão do que é uma referência "favorável” ou "desfavorável”. Na medida em que a unidade de avaliação é a "matéria", não cada enunciado em separado, exige também do pesquisador a capacidade de pesar o conteúdo "favorável" e o "desfavorável", determinando se a resultado pende para um lado ou para o outro - ou se cai na categoria intermediária, "neutro" (Miguel, 2015, p. 172-173).

É no mínimo irônica essa crítica de excesso de subjetividade de um adepto do perspectivismo moral e cognitivo. Mas como o autor nunca explica de 
fato qual sua posição sobre assunto tão crucial para seu próprio argumento. Prefere desfechar críticas ora como perspectivista, ora como paladino da objetividade nas ciências sociais, um paradoxo obviamente insustentável.

Após acusar a MAV de excesso de subjetivismo, Miguel oferece como alternativas para o estudo da mídia a análise de agendamento e de enquadramento. Segundo ele, essas outras metodologias "são de manejo mais sutil e mais complexo exatamente porque o mundo real é mais sutil e mais complexo" (Miguel, 2015, p. 176). A combinação dessas duas coisas, a crítica à suposta subjetividade da MAV e a adesão às metodologias do agendamento e do enquadramento, é eivada de contradições, que são simplesmente ignoradas no texto de Miguel. Tomemos primeiro o agendamento, ou seja, o estudo de como a mídia escolhe publicar temas e tópicos enquanto silencia acerca de outros potencialmente relevantes ao interesse público (Scheufele e Tewksbury, 2007). Quais seriam os critérios para se evitar a subjetividade em análises de agendamento?

Em trabalho anterior, ao comentar análise de agendamento, o próprio Miguel declara, fazendo referência a Claus Offe, que é "sempre complicado trabalhar com aquilo que não está sendo processado, com a potencialidade que não se concretiza” (Miguel, 1999a, p. 254). Basta ler o texto que se segue para termos um exemplo do quão complicado é o emprego desse tipo de análise. Para tentar dar conta de seu argumento, de que houve esvaziamento dos temas políticos no noticiário do Jornal Nacional durante o período da campanha eleitoral de 1998, o autor classifica as notícias da cobertura em temas muito amplos (variedades, esfera pública, outras questões de interesse público e internacional) e agrega o tempo das notícias em cada categoria. Há dois problemas metodológicos encerrados nesse procedimento. Primeiro, não há qualquer referencial comparativo para sabermos se de fato houve silenciamento, mas somente uma comparação entre o tempo dedicado a cada "tema" durante a cobertura de uma campanha, a de 1998, em um meio de comunicação, o Jornal Nacional. Se outros anos da cobertura e outros meios de comunicação com proporções diferentes dos temas fossem usados para contraste, o argumento de Miguel ganharia mais validade. Da maneira como é apresentado, contudo, ele falha ao tentar alcançar, com gráficos e tabelas, a objetividade supostamente almejada em sua análise de agendamento.

O segundo problema é exatamente aquele que Miguel identifica na MAV: a redução da complexidade do objeto. Ora, uma notícia sobre política pode 
ter diferentes intensidades, enquadramentos muito divergentes no que toca este ou aquele candidato, inclusive a valência, que é elemento crucial em coberturas polarizadas. Miguel critica a MAV por reduzir tais intensidades a dois ou três valores (contrário ou favorável; contrário, favorável ou neutro). Sua metodologia, contudo, reduz as intensidades a zero, pois é incapaz de captar qualquer informação dessa natureza. $\mathrm{O}$ objeto é reduzido àquilo que tem de mais inane, de mais despolitizado: seu tema geral.

Em artigo posterior, o autor, aparentemente ciente desse problema metodológico, tenta saná-lo comparando o perfil da cobertura jornalística do Jornal Nacional nas campanhas de 1998 e 2002 (Miguel, 2003). A análise utiliza as mesmas categorias temáticas: variedades, esfera pública, outras questões de interesse público e internacional. Como no artigo anterior, a contagem de tempo das notícias pertencentes a cada categoria gera resultados modestos do ponto de vista da análise política. O leitor é brindado com conclusões deste tipo: "Em 2002, a economia brasileira ocupou 9,4\% do Jornal Nacional - um aumento perceptível em relação aos 6,9\% de 1998” (Miguel, 2003, p. 304). É difícil determinar, contudo, qual a nota que o conceito de "perceptível" obtém na escala entre subjetivismo e objetivismo.

Voltando ao artigo de 1999, sua segunda metade é dedicada à análise de enquadramento da cobertura. Se o estudo do agendamento frequentemente esbarra no problema de se tentar provar uma ausência, as análises de enquadramento já começam por padecer do mal da imprecisão do próprio conceito de "enquadramento". Vários autores identificam esse problema (Campos, 2014; Mendonça e Simões, 2012). O conceito em sua origem dizia respeito a aspectos cognitivos da interação social não mediada, mas passou a ser empregado nos estudos de mídia a aspectos cognitivos da recepção e, depois, a estruturas argumentativas da emissão, sem qualquer referência à recepção. É este último sentido, sintetizado por Robert Entman (1993), que é empregado com mais frequência nos dias de hoje em estudos de mídia ${ }^{4}$. No artigo, Miguel adota explicitamente a definição de Entman.

A primeira coisa a se notar aqui é que essa concepção de enquadramento é monológica: cada texto, argumento, fala, contém enquadramentos que podem ser capturados pelo pesquisador por meio da análise do conteúdo da mensagem.

4 "Enquadrar é selecionar alguns aspectos da realidade percebida e torná-los salientes em um texto comunicativo, de modo a promover uma definição particular de um problema, interpretação causal, avaliação moral ou recomendação de tratamento para o item descrito" (Entman, 1993, p. 53). 
Quando fala dos enquadramentos do Jornal Nacional, Miguel está sistematicamente desprezando a recepção que eles tiveram por parte do público. Ou estaria ele assumindo tacitamente que o público é influenciado por tais enquadramentos veiculados pela imprensa? Seja qual for a resposta, está claro que seu uso da análise de enquadramento se abre à mesma crítica que ele faz à MAV: confundir os diferentes planos da comunicação jornalística. Mas no caso da MAV, pelo menos aquela praticada no Manchetômetro, tal crítica não se aplica, pois não há pretensão de dar conta da recepção, somente da emissão. E aqui nos deparamos com mais uma ironia. Miguel tampouco faz qualquer estudo de recepção. Suas análises, nesses artigos e em outros, se restringem ao plano da emissão. Por que então só a MAV deve ser acusada de desprezar a recepção? A grande mídia adota com abandono critérios mui discricionários de julgamento moral e legal, cotidianamente; nós na academia não podemos nos seduzir por esse vício.

Mas talvez a crítica mais fora do lugar feita à MAV por quem defende análise de enquadramento é que ela padece de falta de objetividade, ou excesso de subjetividade. Imagine, caro leitor, a seguinte experiência. Tomemos um grupo de pessoas, de preferência com formação superior, e peçamos para que codifiquem cem matérias de jornal sobre política, produzidas em período de campanha, utilizando a MAV e a análise de enquadramento. Para tornar as coisas mais realistas, façamos um experimento com enquadramentos preestabelecidos (por exemplo, adotando a tipologia proposta por Mauro Porto (2004) - temático, "corrida de cavalos", personalista ou episódico) e outra codificação livre de enquadramentos, na qual o analista constrói as categorias à medida que a codificação avança, como parece ter sido a maneira empregada por Miguel. Parece-me líquido e certo que os codificadores vão "acertar" e concordar mais frequentemente quanto mais simples e direto forem os códigos aplicados 5 . Assim, a MAV será a metodologia com mais alto grau de concordância, pois não é nada difícil estabelecer, perante uma cobertura altamente politizada, se o texto é positivo, negativo ou neutro em relação a seu objeto. Isso é tão verdadeiro que mesmo se descartarmos todos os aspectos sintáticos e gramaticais dos textos, e os tratarmos como sacos de palavras, somos capazes de produzir análises computacionais de suas valências que se aproximam impressionantemente da codificação humana (entre 80\% e 90\% de acerto) (Hopkins e King, 2010; King, Pan e Roberts, 2013).

5 Na verdade, só podemos testar concordância entre codificadores (inter-rater reliability) e não diretamente a correção de cada codificação. 
Nossos codificadores provavelmente também se sairiam bem ao aplicar uma tipologia simples de enquadramentos preestabelecidos, como a de Porto. Mas certamente haverá mais discordância entre codificadores do que com a aplicação da MAV, pois os enquadramentos de Porto são semanticamente mais complexos, o que gera potencialmente dissonâncias interpretativas. Se a lista de enquadramentos fosse mais longa e semanticamente complexa, como aquela adotada por nós na pesquisa sobre a cobertura da ação afirmativa na grande mídia (Campos, Daflon e Feres Júnior, 2011, 2013; Campos e Feres Júnior, 2013), o problema de potencial discordância seria ainda mais intenso.

Resta avaliar comparativamente ao grau de subjetividade envolvido em fazer análise de enquadramento livre, ou seja, sem uma lista preconcebida e testada. É exatamente isso que Miguel faz em seus textos. No artigo de 1999, a palavra "enquadramento" é usada 23 vezes, mas seu emprego é tão frouxo do ponto de vista conceitual que sequer é possível determinar quais e quantos foram eles durante aquela campanha. Assim, voltando ao nosso experimento, qual a probabilidade de as pessoas em nosso grupo de codificadores, se apresentadas com o material estudado por Miguel, e sem conhecimento prévio de seu trabalho, produzirem análise de enquadramento similar à dele? Tal probabilidade não é tão diminuta quanto a de um macaco datilografar as obras completas de Shakespeare, mas é muito pequena, certamente bem menor do que o nível de concordância obtida com o emprego da MAV.

Tais resultados hipotéticos não são surpreendentes se nos dermos conta de que a MAV não é nada mais do que uma análise de enquadramento. Ela avalia o sentimento ou sentido do texto em relação a seu objeto. Ou seja, a notícia contrária corresponde ao enquadramento negativo dado ao objeto, aquele que aponta para seus defeitos, vícios, incompetências etc., e a favorável, ao enquadramento positivo, aquele que ressalta suas virtudes, atributos louváveis, capacidade de ação etc. Ela é uma análise de enquadramentos de valores extremos, que se aplica a materiais muito polarizados. Portanto, é mais impermeável às variações da interpretação subjetiva do que análises de enquadramento semanticamente mais complexas.

\section{Conclusão}

Como pretendo ter mostrado neste artigo, as críticas que Miguel dirige à MAV são em sua maior parte infundadas e frequentemente contradizem os trabalhos do próprio autor sobre o tema da mídia. Élamentável que uma crítica 
com intenções destrutivas como essa advenha de alguém tão importante no desenvolvimento dos estudos de mídia e política em nosso país, particularmente porque o oligopólio da grande mídia brasileira tem militado consistentemente contra o aprofundamento da democracia no Brasil. Na verdade, necessitamos de mais trabalhos que exponham a vileza e a baixa qualidade da cobertura jornalística que é oferecida a nossos cidadãos diariamente. Mais análises de valência, mais análises de agendamento, mais análises de enquadramento, se possível integradas. Infelizmente, salvo mui meritórias exceções, os estudos de mídia e política continuam inanes dentro da ciência política, e nos programas de comunicação eles oscilam entre o ceticismo pós-moderno apolítico e a reverência aos poderes midiáticos estabelecidos há décadas em nosso país.

A MAV não é capaz de dar conta sozinha da imensa tarefa de se estudar criticamente a mídia. Nunca foi essa sua pretensão. Contudo, a partir do momento que contamos valências é possível, sim, estabelecer menor ou maior viés de um determinado meio de comunicação em relação a tal ou qual objeto - esse é um dos principais objetivos do emprego da MAV. Ela é ótima como instrumento de avaliação do mundo real de uma mídia militante, que se encontra extremamente politizada, nas mãos de poucos grupos familiares, todos concentrados na mesma região do espectro político-ideológico. Essa é a grande virtude da MAV. Só não vê quem não quer.

\section{Referências}

ARISTÓTELES [ARISTOTLE] (2000). Nicomachean ethics. Ed. Roger Crisp. Cambridge, New York: Cambridge University Press (Cambridge Texts in the History of Philosophy).

ARRUDA, Lilian Rose (1995). "O vôo das notícias: o Jornal Nacional e as eleições 94”. Dissertação (mestrado) em ciências sociais. São Paulo: Pontifícia Universidade Católica.

AZEVEDO, Fernando (2000). "Imprensa, campanha presidencial e agenda da mídia”, em RUBIM, Antonio Albino Canelas (org.). Mídia e eleições de 98. João Pessoa, Salvador: Editora da UFPb, Facom.

BIROLI, Flávia \& MIGUEL, Luis Felipe (2010). "A produção da imparcialidade: a construção do discurso universal a partir da perspectiva jornalística”. Revista Brasileira de Ciências Sociais, v. 25, n. 73, p. 59-76.

(2013). "Meios de comunicação, voto e conflito político no Brasil". Revista Brasileira de Ciências Sociais, v. 28, n. 81, p. 78-95. 
CAMPOS, Luiz Augusto (2014). "A identificação de enquadramentos através da análise de correspondências: um modelo analítico aplicado à controvérsia das ações afirmativas raciais na imprensa”. Opinião Pública, v. 20, n. 3, p. 377-406.

CAMPOS, Luiz Augusto; DAFLON, Verônica Toste \& FERES JÚNIOR, João (2011). "Fora de quadro: a ação afirmativa nas páginas d'O Globo". Contemporânea - Revista de Sociologia da UFSCar, n. 2, p. 61-83.

(2013). "Administrando o debate público: O Globo e a controvérsia em torno das cotas raciais". Revista Brasileira de Ciência Política, n. 11, p. 7-31.

CAMPOS, Luiz Augusto \& FERES JÚNIOR, João (2013). “A Folha de S. Paulo e as ações afirmativas: dez anos de cobertura (2001-2011)". Textos para discussão GEMAA, n. 3. Rio de Janeiro: Iesp/Uerj.

CAMPOS, Luiz Augusto \& MACHADO, Carlos (2015). "A cor dos eleitos: determinantes da sub-representação política dos não brancos no Brasil". Revista Brasileira de Ciência Política, n. 16, p. 121-151.

COLLING, Leandro (2000). "Agendamento, enquadramento e silêncio no Jornal Nacional nas eleições presidenciais de 1998”. Dissertação (mestrado) em comunicação e cultura contemporânea. Salvador: Facom/UFBA.

DAFLON, Verônica Toste \& FERES JÚNIOR, João (2012). “Ação afirmativa na revista Veja: estratégias editoriais e o enquadramento do debate público “ Compolítica, v. 2, n. 2, p. 66-91.

DERRIDA, Jacques (1978). Writing and difference. Chicago: University of Chicago Press.

ENTMAN, Robert M. (1993). "Framing: toward clarification of a fractured paradigm”. Journal of Communication, v. 43, n. 4, p. 51-8.

FERES JÚNIOR, João \& Verônica Toste DAFLON (2015). “A nata e as cotas raciais". Opinião Pública, v. 21, n. 2, p. 238-67.

EISENBERG, Zena Winona; FERES JÚNIOR, João \& NASCIMENTO, Leonardo Fernandes (2013). "Monteiro Lobato e o politicamente correto". Dados, n. 56, p. 69-108.

FIGUEIREDO, Roseli Rossi (1996). "Mídia e eleições: um estudo de caso sobre o noticiário da campanha presidencial de 1994". Dissertação (mestrado) em ciências sociais. São Carlos (SP): UFSCar.

FOUCAULT, Michel (1979). Microfísica do poder. Rio de Janeiro: Graal. 
FRY, Peter \& MAGGIE, Yvonne (2003). “Questões de taxonomia, ou como o Brasil se tornou um país de brancos e negros na era das cotas". XXIII Reunião Anual da Anpocs. Caxambu (MG), 21-25 out.

(2004). "A reserva de vagas para negros nas universidade brasileiras". Estudos Avançados, n. 18, p. 50.

GOFFMAN, E. (1974). Frame analysis: an essay on the organization of experience. London: Penguin.

GONÇALVES, Elias Machado (1996). "A autonomia dos sentidos como conflito ético na comunicação política”, em FAUSTO NETO Antonio \& PINTO, Milton José (orgs.). O indivíduo e suas mídias. Rio de Janeiro: Diadorim, Compós.

HASENBALG, Carlos (1992). Relações raciais no Brasil contemporâneo. Rio de Janeiro: Rio Fundo, Iuperj.

HASENBALG, Carlos \& SILVA, Nelson do Valle (1988). Estrutura social, mobilidade e raça. Rio de Janeiro: Iuperj.

HOPKINS, Daniel J. \& KING, Gary (2010). "A method of automated nonparametric content analysis for social science”. American Journal of Political Science, v. 54, n. 1, p. 229-47.

KING, Gary; PAN, Jennifer \& ROBERTS, Margaret E. (2013). "How censorship in china allows government criticism but silences collective expression”. American Political Science Review, v. 107, n. 2, p. 1-18.

KUCINSKI, Bernardo (1998). "O ataque articulado dos barões da imprensa: a mídia na campanha presidencial de 1989”, em KUCINSKI, Bernardo (org.). A síndrome da antena parabólica: ética no jornalismo brasileiro. São Paulo: Editora Fundação Perseu Abramo.

LAMOUNIER, Bolívar (1983) A ciência política nos anos 80. Brasília: Editora da UnB

LEITE, Fernando (2015). “O campo de produção da ciência política brasileira contemporânea: uma análise histórico-estrutural de seus princípios de divisão a partir de periódicos, áreas e abordagens". Tese (doutorado) em ciência política. Curitiba: UFPR.

MACHADO, Carlos \& MIGUEL, Luis Felipe (2011). “Padrões de coesão e dispersão: uma proposta de tipologia para coligações”. Teoria \& Pesquisa, n. 20, p. 37-58.

MARENCO, André (2015). "When institutions matter: CAPES and political science in Brazil". Revista de Ciencia Política, v. 35, n. 1, p. 33-46. 
MENDONÇA, Ricardo Fabrino \& SIMÕES, Paula Guimarães (2012). "Enquadramento: diferentes operacionalizações analíticas de um conceito". Revista Brasileira de Ciências Sociais, v. 27, n. 79 , p. 187-201.

MIGUEL, Luis Felipe (1999a). "Mídia e eleições: a campanha de 1998 na Rede Globo”. Dados, v. 42, n. 2, p. 253-76.

(1999b). "Mídia e manipulação política no Brasil: a Rede Globo e as eleições presidenciais de 1989 a 1998”. Comunicação \& Política, v. VI, n. 2-3. (2002a). "O Jornal Nacional e a reeleição", em Política e mídia no Brasil. Brasília: Plano Editorial.

(2002b). "Os meios de comunicação e a prática política”. Lua Nova: Revista de Cultura e Política:155-184.

(2003). “A eleição visível: a Rede Globo descobre a política em 2002”. Dados, v. 46, n. 2, p. 289-310.

(2004a). "A descoberta da política - a campanha de 2002 na Rede Globo”, em Eleições presidenciais em 2002: ensaios sobre mídia, cultura e política. (org.) Hacker Editores, p. 95-105. São Paulo: Hacker Editores. (2004b). "Discursos cruzados: telenoticiários, HPEG e a construção da agenda eleitoral”. Sociologias, p. 238-258.

(2004c). "Modelos utópicos de comunicação de massa para a democracia”. Comunicação \& Política, v. 22, n. 3, p. 129-47.

(2011). "Representação democrática: autonomia e interesse ou identidade e advocacy". Lua Nova, n. 25-63.

(2015). “Quanto vale uma valência?” Revista Brasileira de Ciência Política, n. 17, p. 165-78.

PORTO, Mauro (2004). "Enquadramentos da mídia e política”, em RUBIM, Antonio Albino Canelas (org.). Comunicação de política. Salvador: Edufba.

SCHEUFELE, Dietram A. \& David TEWKSBURY (2007). "Framing, agenda setting, and priming: the evolution of three media effects models". Journal of Communication, n. 57, p. 9-20.

SCHWARTZMAN, Simon (1999). "Fora de foco: diversidade e identidades étnicas no Brasil”. Novos Estudos CEBRAP, n. 55, p. 83-96.

SILVA, Nelson do Valle (1978). "Black-white income differentials in Brazil, 1960". Tese (doutorado) em sociologia. Ann Arbor (MI): University of Michigan. (1981). "Cor e o processo de realização sócio-econômica". Dados, v. 24 , n. 3, p. 391-409. 
SOUZA, Diana Paula de (2009). "Caso Abílio Diniz: libertação do empresário, produção da opinião pública e promulgação da Lei de Crimes Hediondos”. VII Encontro Nacional de Pesquisadores em Jornalismo. São Paulo, 25-27 nov.

\section{Resumo}

O artigo é uma resposta sistemática e detalhadas às críticas que Luis Felipe Miguel fez em artigo recente à metodologia da análise de valência (MAV). Segundo o autor: (1) a MAV confunde emissor, receptor, pesquisador e objeto do discurso; (2) reduz drasticamente a complexidade do processo comunicativo; (3) reproduz o ideal normativo da imparcialidade jornalística; (4) está sujeita à excessiva subjetividade. Pretendo mostrar que esses argumentos arrolados por Miguel contra a MAV são, quando não equivocados, superficiais. Contra suas críticas argumento que: (1) estudos de valência focam somente o emissor, sem prejuízo para a análise; (2) reduzem complexidade como outras metodologias em ciências sociais; (3) não dependem do pressuposto da imparcialidade para serem feitos; (4) estão menos sujeitos às distorções subjetivas do que metodologias de estudo da mídia como análise de agendamento e de enquadramento, preconizadas por Miguel.

Palavras-chave: análise de valências, estudos de mídia, estudos eleitorais, objetividade, viés de mídia.

\section{Abstract}

This article is a reply to the criticism raised by Luis Felipe Miguel in a recent piece against the use of the methodology of sentiment analysis (MSA) in media studies. According to this author, the MSA is flawed because (1) it confuses different levels of communication, chiefly emission with reception; (2) it reduces drastically the complexity of the communicative process; (3) it adopts unreflexively the normative ideal of journalistic neutrality; and (4) it is plagued with an excess of subjectivism. I intend to show that the points made by Miguel against the MSA are either equivocal or superficial. Against them I argue that the MSA (1) focuses on the content of emission but not reception, and that does not stop it from producing meaningful results; (2) reduces the complexity of its subject matter like all other scientific methodologies, and does it in a way that is appropriate to the nature of its subject matter; (3) does not depend on the premise of journalistic neutrality to be valid; and (4) is less subjected to the distortions introduced by the excess of subjective judgement calls than other concurring methodologies such as agenda setting and frame analysis, both advocated by Miguel.

Keywords: sentiment analysis, media studies, election studies, objectivity, media bias. 